\title{
Recent Ostracods of the Superfamilies Cytheroidea and Darwinuloidea (Crustacea) from Lake Biwa, a Japanese Ancient Lake
}

\author{
Robin J. Smith ${ }^{1}$ and Horst Janz ${ }^{2}$ \\ ${ }^{1}$ Lake Biwa Museum, 1091 Oroshimo, Kusatsu, Shiga, 525-0001 Japan \\ E-mail:smith@lbm.go.jp \\ ${ }^{2}$ Rappenberghalde 82, D-72070 Tübingen, Germany \\ E-mail:janz@gss-tuebingen.de
}

(Received 5 February 2009; Accepted 10 August 2009)

\begin{abstract}
Seven species of the ostracod superfamily Cytheroidea and four species of the superfamily Darwinuloidea were recovered from Lake Biwa in west-central Japan. Four of the cytheroidean species are newly described herein, all belonging to the genus Limnocythere: $L$. kamiyai sp. nov., $L$. fude sp. nov., $L$. levigatus sp. nov., and L. cyphoma sp. nov. Two others are new records for Lake Biwa, namely Limnocythere stationis Vávra, 1891 and Metacypris digitiformis Smith and Hiruta, 2004. The four newly described Limnocythere species may be an example of a small endemic species flock. Of the Darwinuloidea recovered, two species, Darwinula stevensoni (Brady and Robertson, 1870) and Vestalenula sp., have been previously recorded from the lake. Vestalenula sp. is herein identified as V. cylindrica (Straub, 1952), which was previously known only as a fossil from Europe and the Middle East: this is the first report of a living population. The two other darwinulid species, also belonging to the genus Vestalenula, are new records for Japan, namely Vestalenula lundi (Neale and Victor, 1978) and V. molopoensis (Martens and Rossetti, 1997). Their discovery in Lake Biwa dramatically extends the known distribution of all three Vestalenula species by thousands of kilometers and increases the number of darwinulids known in Japan from three to five.

Key Words: Crustacea, Ostracoda, Darwinuloidea, Cytheroidea, Lake Biwa, Limnocythere, Vestalenula, ancient lake.
\end{abstract}

\section{Introduction}

Lake Biwa is an ancient lake located in Shiga Prefecture, west-central Japan (Fig. 1), with a continuous history of lacustrine habitats stretching back one million years. Additionally, a series of four palaeo-lakes existed to the southeast of the present lake from about 4 million to 1.8 million years ago (Meyers et al. 1993; Nakajima and Nakai 1994). Like other ancient lakes of the world, it has a number of endemic species, representing approximately $9 \%$ of the reported fauna (Mori and Miura 1990; Nishino and Watanabe 2000). For detailed overviews of Lake Biwa, see Nakajima and Nakai (1994) and Rossiter (2000).

Recently, 18 species of ostracods of the family Candonidae (superfamily Cypri- 


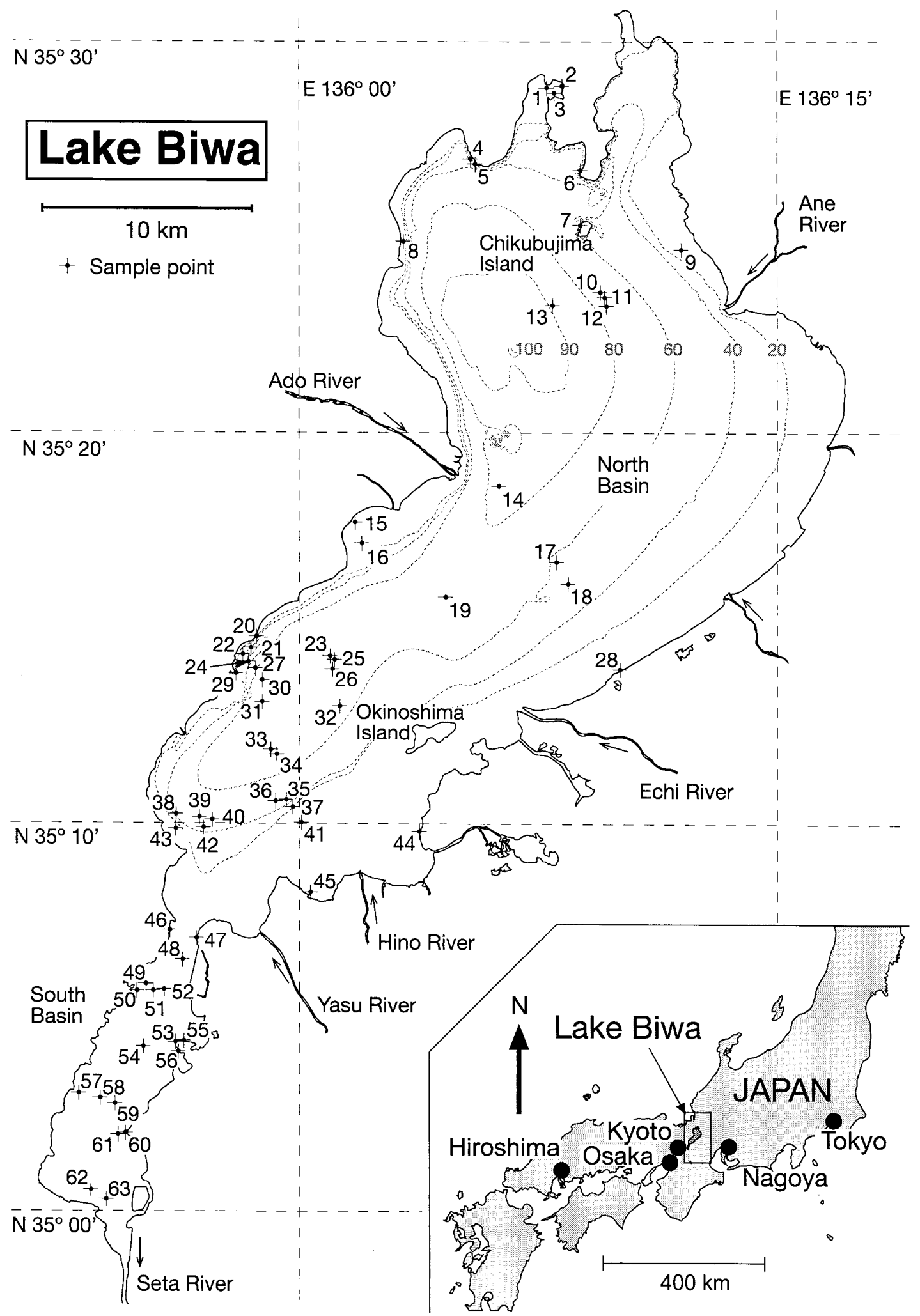

Fig. 1. Location of Lake Biwa and sampling localities. 
doidea) have been reported from Lake Biwa, 11 of which were newly described (Smith and Janz 2008). Other groups of ostracods in Lake Biwa are poorly known, and the aim of this paper is to document the species of the superfamilies Cytheroidea and Darwinuloidea recovered from the lake between 1999 and 2007.

Cytheroidean ostracods are relatively diverse in freshwater habitats, but in Japan only a small number have been recorded: Cytherissa lacustris (Sars, 1863) and some unidentified Limnocythere species from Lake Biwa, an unidentified species of Cytheroidea from western Japan, and two species in Hokkaido, Metacypris digitiformis Smith and Hiruta, 2004 and Uncinocythere occidentalis (Kozloff and Whitman, 1954) (Smith and Kamiya 2001; Okubo 2004; Smith and Hiruta 2004).

The family Darwinulidae is the only extant family of the suborder Darwinulocopina, and although it was the first ostracod group to colonize freshwater habitats (in the Carboniferous, over $350 \mathrm{Ma}$ ), today it is of low diversity with only about 30 extant species known worldwide (Horne 2003). A small number of darwinulid species, in particular Darwinula stevensoni (Brady and Robertson, 1870), have a widespread or cosmopolitan distribution, but most species are known from much more restricted geographical ranges, or even just from their type localities (Artheau 2007). The group has been noted as being particularly rare in the world's few ancient lakes (Martens 1994). Previously, only two darwinulid species were known from Lake Biwa, Darwinula stevensoni and Vestalenula sp. (Okubo 2001; Smith and Kamiya 2008), and only one other darwinulid species, Vestalenula cornelia Smith, Kamiya and Horne, 2006, was known from the Japanese archipelago (Smith et al. 2006).

Samples from 63 localities (Fig. 1) in Lake Biwa taken between 1999 and 2007 yielded seven cytheroidean and four darwinulid species.

\section{Material and Methods}

Shore samples were taken by scooping up sediment and washing it through a $125 \mu \mathrm{m}$ sieve, before transferring the residue to a sample bottle. Offshore samples were taken from a boat with an Ekman sediment grab. The recovered sediment was washed through a $200 \mu \mathrm{m}$ Böttger net on a long pole submerged in the lake from the boat. The resulting residue was then transferred to a sample bottle. Samples were kept cool and live specimens were picked from them under a binocular microscope. For storage, picked specimens were transferred to small vials containing $70 \%$ ethanol.

Latitudes and longitudes were recorded using a hand-held Garmin GPS unit, using the Tokyo datum.

Appendages were dissected and mounted in glycerine on glass slides and drawn with the aid of a camera lucida. Carapaces are stored dry in micropalaeontological cavity slides. Carapaces used for SEM investigation were coated with gold before being photographed with a JEOL 5800 LV scanning electron microscope.

All type specimens of new species described herein are held at the Lake Biwa Museum (numbers: LBM 1430003497 to 1430003538). SMNS numbers refer to material held at the Staatliches Museum für Naturkunde Stuttgart, Germany.

Abbreviations used in the text are as follows: An1, antennule; An2, antenna; 
$\mathrm{cp}$, copulatory process; dl, distal lobe; Md, mandible; Mx, maxillula; L5, fifth limb; L6, sixth limb; L7, seventh limb; UR, uropodal ramus; CS, caudal seta; FRO, female reproductive organ; Hp, hemipenis. Terminology of the appendages follows that of Rossetti and Martens (1998), Meisch (2007), and Smith and Kamiya (2008).

Synonymy lists in the Systematics section below are abbreviated and only show the first recorded name of the species, subsequent nomenclature changes, and junior synonyms.

\title{
Systematics
}

\author{
Superfamily Cytheroidea Baird \\ Family Limnocytheridae Klie \\ Subfamily Limnocytherinae Klie \\ Genus Limnocythere Brady \\ Limnocythere stationis Vávra, 1891
} (Figs $2 \mathrm{~A}-\mathrm{C}, 3$ )

Limnocythere stationis Vávra, 1891: 108, fig. 38.

Material examined. 1 male and 2 females (LBM 1430003497), 1 male (LBM 1430003498), 1 male (LBM 1430003499), and 1 female (LBM 1430003500), Lake Biwa, north basin, $35^{\circ} 28^{\prime} 40.6^{\prime \prime} \mathrm{N}, 136^{\circ} 08^{\prime} 07.1^{\prime \prime} \mathrm{E}$, rocky shore with pebbles, coarse sand, and reeds, depth $0.2 \mathrm{~m}, 21$ September 2006 .

Description. Female carapace length $351-363 \mu \mathrm{m}$, height $211-221 \mu \mathrm{m}(\mathrm{H} / \mathrm{L}=$ $0.60)$, male carapace length $360-370 \mu \mathrm{m}$, height $188-195 \mu \mathrm{m}(\mathrm{H} / \mathrm{L}=0.51-0.54)$. Female in lateral view with maximum height at anterior quarter (Fig. 2A). Dorsal margin straight, gently sloping down to evenly curved posterior margin. Anterior margin evenly rounded. Ventral margin slightly concave. Sulcus at mid-length. Each valve with tubercle on either side of sulcus near dorsal margin, a third tubercle at center point of carapace, and one posteroventral ala (Fig. 2C). Surface of carapace with numerous coarse pits. Male more elongate than female with longer hinge (Fig. 2B). Ornamentation features of male carapace in similar position to those of female, but slightly less developed, especially posteroventral ala.

Appendages of female closely matching those reported for European female specimens (e.g., Meisch 2000), including reduced L7. Male An1, Md, Mx, L5, and L7 (Fig. 3A, D, E, F, H) very similar to those of female. Male An2 with anterior distalmost claw bifurcated towards distal end (Fig. 3B, C) (not bifurcated in female). L6 of male (Fig. $3 \mathrm{G}$ ) with proportionally shorter terminal claw than in female. Brush-

Fig. 2. Limnocythere stationis Vávra, 1891 (A-C), L. kamiyai sp. nov. (D-F), and L. fude sp. nov. (G-I). A, Right view of female carapace; B, right view of male carapace; C, dorsal view of female carapace, anterior to right; $\mathrm{D}$, right view of female carapace; $\mathrm{E}$, right view of male carapace; F, dorsal view of female carapace, anterior to right; $G$, right view of female carapace; $\mathrm{H}$, right view of male carapace; I, dorsal view of female carapace, anterior to right. A-C, LBM 1430003497; D, F, LBM 1430003501, paratype; E, LBM 1430003502, paratype; G, I, LBM 1430003506, paratype; H, LBM 1430003505, paratype. 


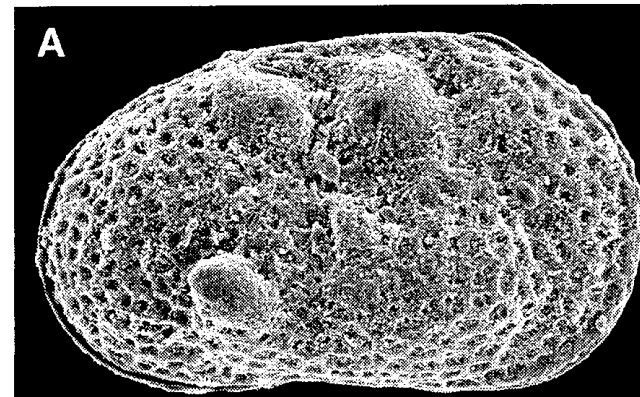

q
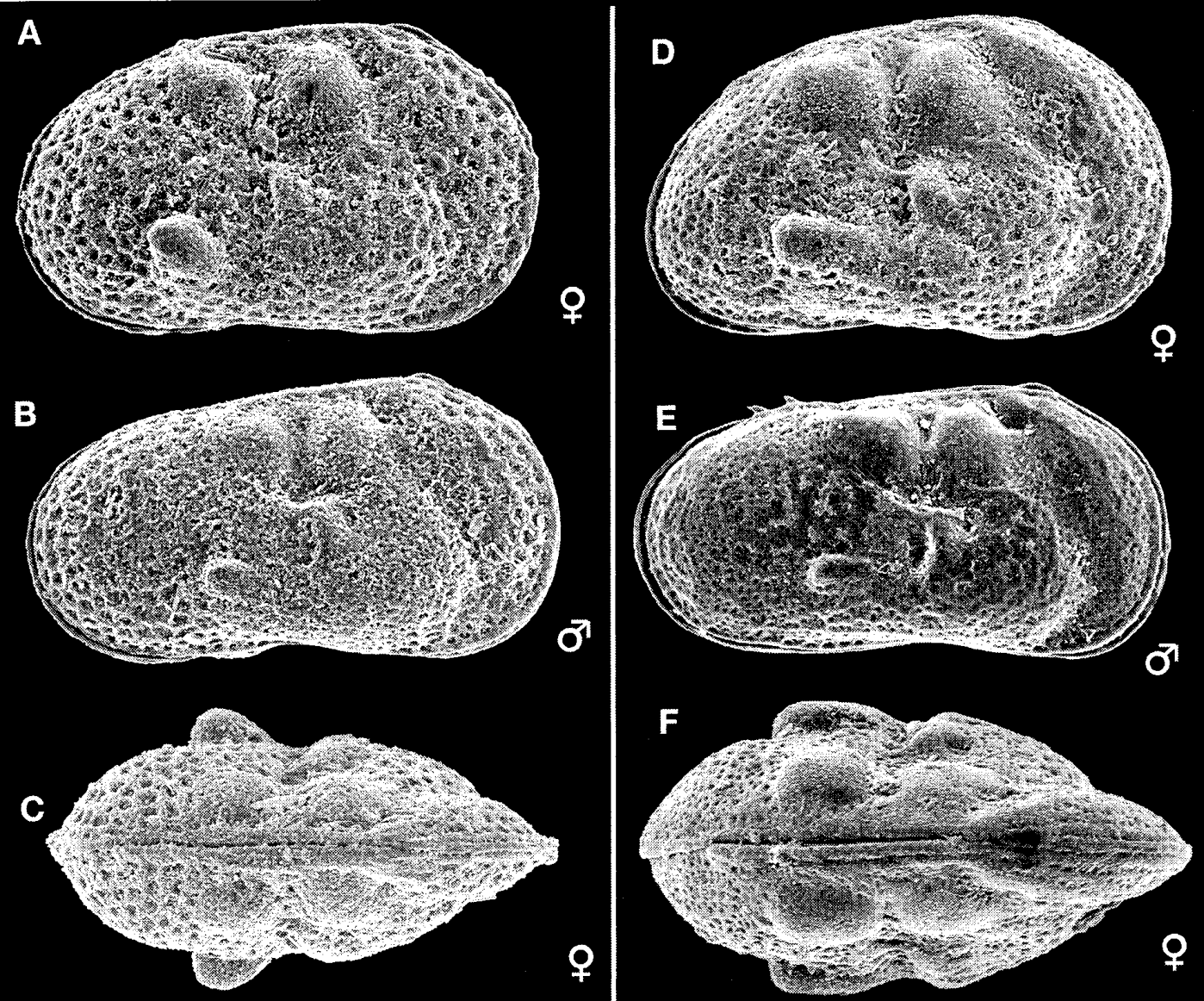

3

\section{Limnocythere stationis}
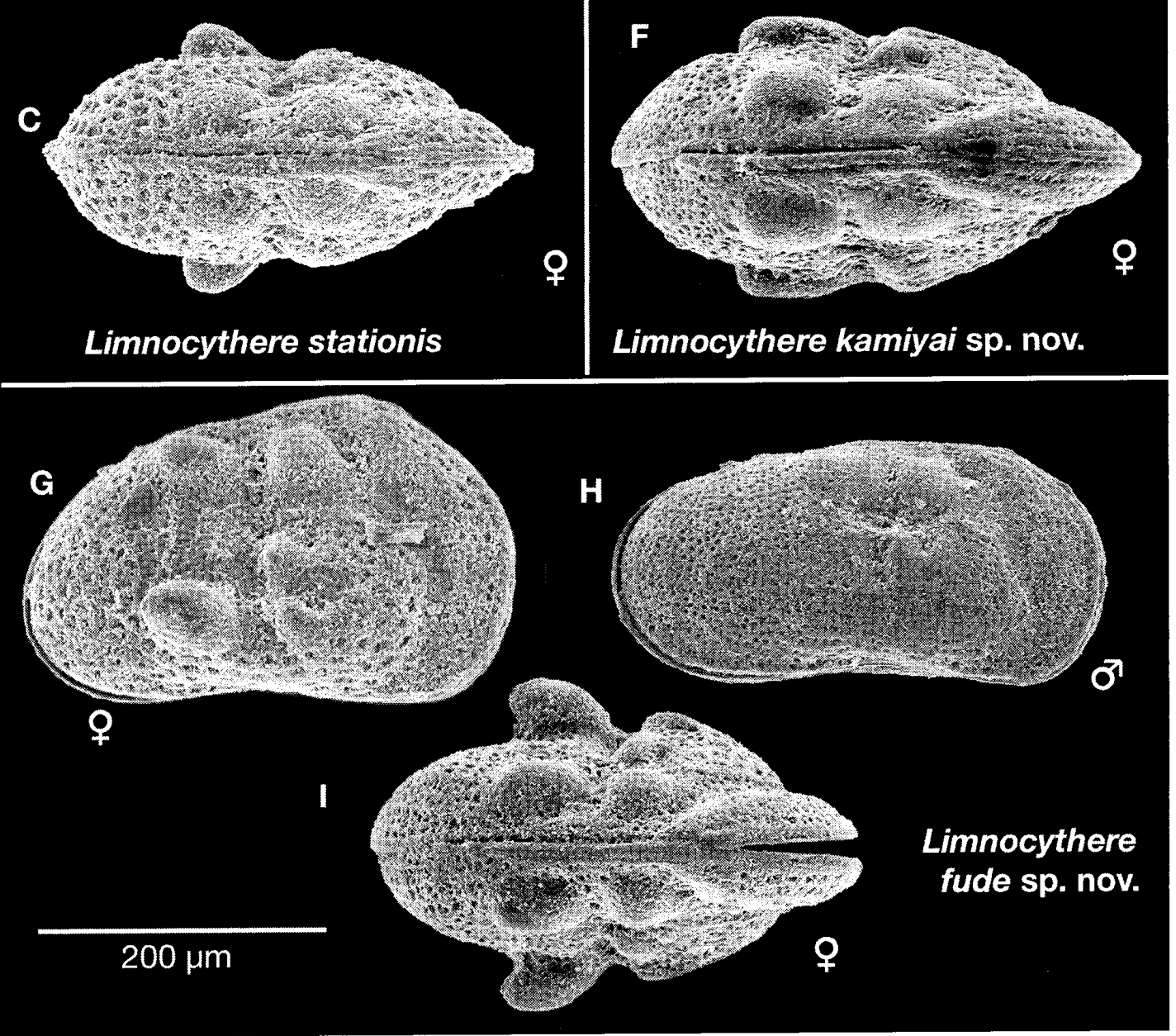


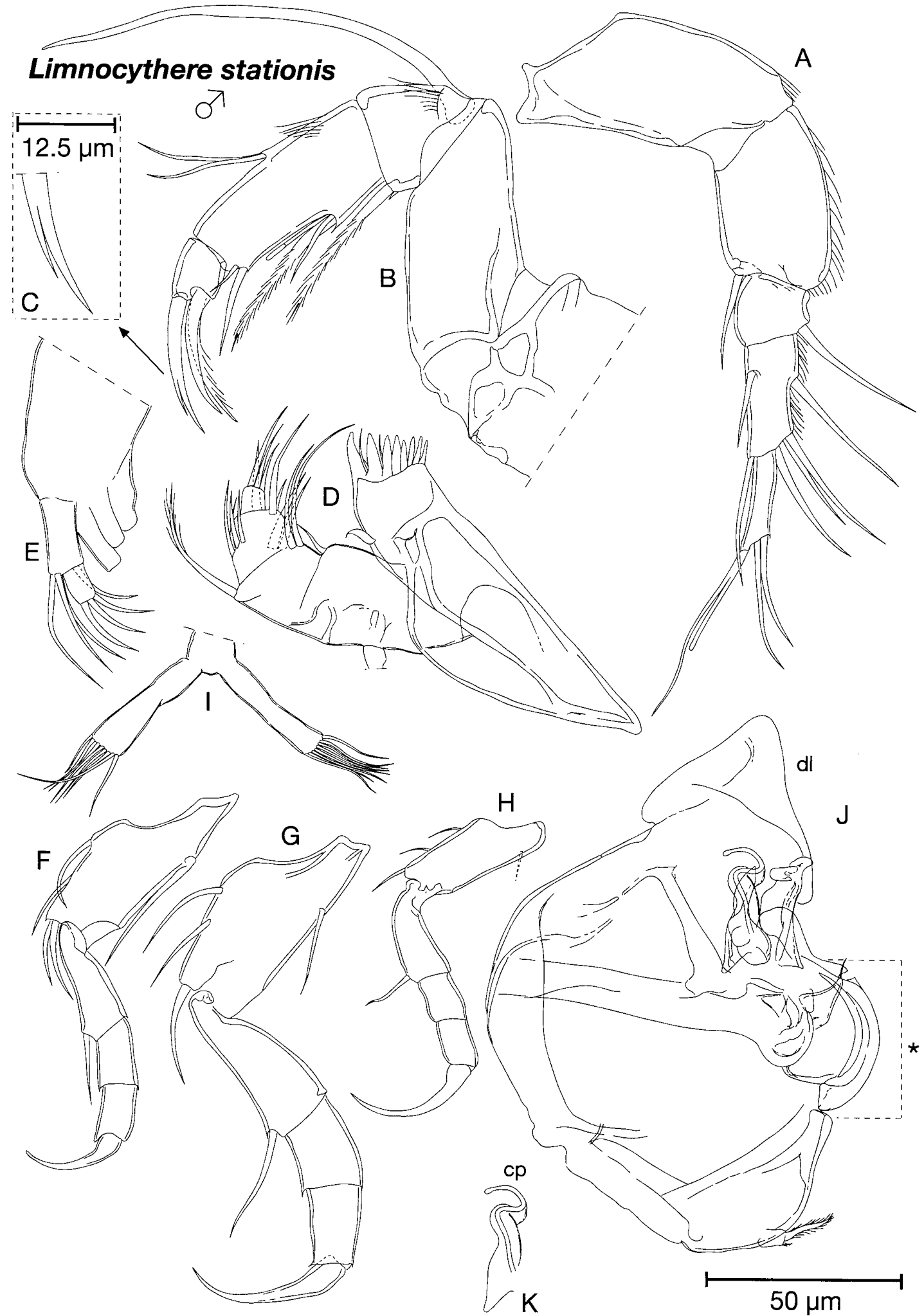

Fig. 3. Limnocythere stationis Vávra, 1891, males, LBM 1430003498 (A-D, F-H, J, K) and LBM 1430003499 (E, I). A, An1; B, An2; C, detail of distal-most claw of An2; D, Md; E, Mx (setae on endites not drawn); F, L5; G, L6; H, L7; I, brush-shaped organs; J, Hp; K, cp of Hp. 
shaped organs well developed, with long, slender segment supporting numerous setae (Fig. 3I). Hp relatively large, with broadly rounded outer margin and with large, triangular dl (Fig. 3J). Below dl, inner margin with well-sclerotized, rounded lobe (marked with asterisk in Fig. 3J). Cp relatively short, thickened proximally, and narrow and sinuous distally (Fig. 3K).

Remarks. In lateral and dorsal views the Lake Biwa specimens closely match Limnocythere stationis reported from Europe except for missing the denticles on the posterior-dorsal margin of the right valve (cf. Meisch 2000, fig. 177A). Martens (1984) reported female specimens from Sudan also missing these denticles. The specimens from Sudan had longer claws on the antennae than both European (as figured by Meisch 2000, fig. 177D) and Japanese specimens.

This is the first confirmed record of this species in Japan, although Okubo (2004) noted that an unidentified species from Lake Biwa resembles L. stationis. Other localities include Western Europe (Meisch 2000), Sudan (Martens 1984), South Africa, Uzbekistan, the Far-East of Russia, Korea, and China (Schornikov and Trebukhova 2001; Schornikov 2004; Yu et al. 2005). Schornikov (2004) figured a male carapace from the region of Peter the Great Bay, Far-East of Russia, which closely matches the male carapaces found in Lake Biwa. The single valve figured by Martens (1984) of a possible male of this species from Sudan is considerably different in shape to males from both the Far-East of Russia and Lake Biwa. Herein is the first description of the sexually dimorphic appendages of the male of this species.

In Lake Biwa this species was found twice, at a depth of $0.2 \mathrm{~m}$ among pebbles and coarse sand, and at $16 \mathrm{~m}$ in sandy mud. Localities (Fig. 1): 2, 41.

\section{Limnocythere kamiyai sp. nov.}

(Figs 2D-F, 4A, B)

Material examined. Holotype: male (LBM 1430003503), dissected, Lake Biwa, southern basin, east shore, $35^{\circ} 02^{\prime} 01.5^{\prime \prime} \mathrm{N}, 135^{\circ} 54^{\prime} 36.5^{\prime \prime} \mathrm{E}$, coarse, poorly sorted angular sand with a little organic detritus, depth $0.1 \mathrm{~m}, 23$ November 2005 . Allotype: female (LBM 1430003504), dissected, same data as holotype. Paratypes: whole male (LBM 1430003502) and whole female (LBM 1430003501), same data as holotype.

Diagnosis. Carapace small, with male much more elongate than female. Dorsal margin of female gently curved, sloping down at approximately $8^{\circ}$ from point of maximum height, this being situated at anterior quarter. Male with straight dorsal margin and with two denticles on postero-dorsal margin of right valve. Valves of both sexes with sulcus, three tubercles, and postero-ventral ala. Anterior end beaklike in dorsal view. L7 reduced, much smaller than both L5 and L6. Male Hp with trapezoidal $\mathrm{dl}$ and very elongate $\mathrm{cp}$.

Description. Female carapace length $363-403 \mu \mathrm{m}$, height $221-240 \mu \mathrm{m}(\mathrm{H} / \mathrm{L}=$ $0.58-0.63)$, male length $325-344 \mu \mathrm{m}$, height $175-188 \mu \mathrm{m}(\mathrm{H} / \mathrm{L}=0.54-0.55)$. Maximum height of female in lateral view at anterior quarter (Fig. 2D). Dorsal margin gently curved, sloping down at approximately $8^{\circ}$ to relatively tightly curved posterior margin. Apex of curve of posterior margin below mid-height, less inflated than anterior margin. Ventral margin slightly concave. Sulcus at mid-length. Large tubercle on either side of sulcus near dorsal margin, third tubercle at center point of 
carapace (Fig. 2F). Large, angular ala posterior of sulcus near ventral margin (elongate in dorsal view). Surface of carapace with numerous small pits, less abundant in central area. Left valve overlapping right along posterior margin. Male $(\mathrm{H} / \mathrm{L}=0.50)$ more elongate than female $(\mathrm{H} / \mathrm{L}=0.60)$ with longer and straighter hinge and two denticles on postero-dorsal margin of right valve (Fig. $2 \mathrm{E}$ ). Sulcus and tubercles in similar position to those of female, but slightly less developed.

Appendages of both male and female very closely matching those of $L$. stationis with exception of $\mathrm{Hp}$. Hp with rounded outer margin and dl tapering to trapezoidally truncated end (Fig. 4A). Inner margin concave, with small, rounded projection supporting approximately ten fine setae. Below projection inner margin well-sclerotized and slightly curved (marked with asterisks in Fig. 4A). Cp very elongate, proximally strongly curved and thickened, tapering to long, flexible distal part (Fig. 4B).

Remarks. The carapace of this species closely resembles that of Limnocythere stationis. Differences include a more tightly curved posterior margin, more steeply sloping dorsal margin, and shallower pits in L. kamiyai. Additionally, the $\mathrm{Hp}$ of this species is significantly different to that of $L$. stationis, with the $\mathrm{dl}$ and $\mathrm{cp}$ clearly distinguishing the two species (compare Fig. 3J, K with Fig. 4A, B). Limnocythere xinanensis Zhao, 1987 from Pleistocene to Recent sediments of Guizhou and Yunnan Provinces, China, is also similar to this new species, but the female carapace of the former is slightly more elongated, the dorsal margin straighter, the posterior margin more evenly rounded, and the dorsal view narrower compared with L. kamiyai. Males of L. xinanensis were reported, but not figured (Zhao 1987), and the appendages of this species remain unknown.

A third species that resembles Limnocythere kamiyai is Limnocythere dorsosicula De Deckker, 1981, reported from inland waters of Australia. The carapace of $L$. dorsosicula is most similar to that of $L$. stationis in that the posterior margin of the female is more inflated than in $L$. kamiyai. The $\mathrm{Hp}$ of $L$. dorsosicula is also most similar to that of L. stationis, especially the well-sclerotized, rounded lobe on the inner margin below dl. However, De Deckker (1981) reported that the L7 is the largest walking leg in $L$. dorsosicula, in contrast to any of the Limnocythere species from Lake Biwa, in which this limb is the smallest walking leg.

Limnocythere kamiyai was found twice, at a depth of $0.1 \mathrm{~m}$ in a substrate of coarse, angular, poorly sorted sand, and a depth of $5.5 \mathrm{~m}$ on sandy mud. Localities (Fig. 1): 45, 60.

Etymology. Named in honour of Professor Takahiro Kamiya (University of Kanazawa, Japan).

Limnocythere fude sp. nov.

(Figs 2G-I, 4E, F)

Material examined. Holotype: male (LBM 1430003507), dissected, Lake Biwa, north basin, off western shore, $35^{\circ} 17^{\prime} 09.3^{\prime \prime} \mathrm{N}, 136^{\circ} 01^{\prime} 58.5^{\prime \prime} \mathrm{E}$, substrate of poorly sorted, angular sand and gravel, depth $9.7 \mathrm{~m}, 19$ August 2006. Allotype: female (LBM 1430003508), dissected, same data as holotype. Paratypes: whole male (LBM 1430003505) and whole female (LBM 1430003506), same data as holotype.

Diagnosis. Carapace small, less than $400 \mu \mathrm{m}$ in length, with female much less 
Limnocythere kamiyai sp. nov.

Limnocythere levigatus sp. nov.
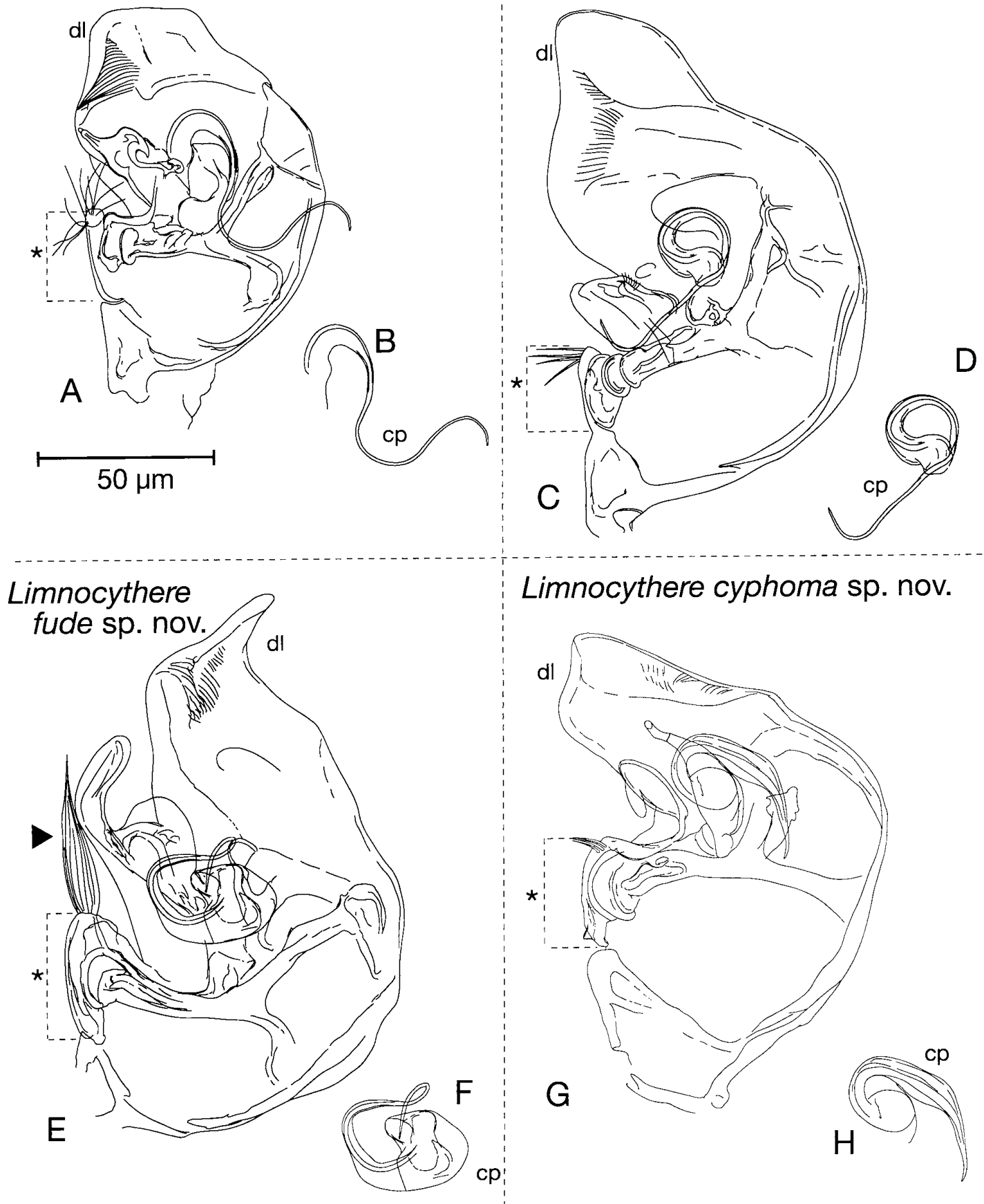

\section{Limnocythere cyphoma sp. nov.}

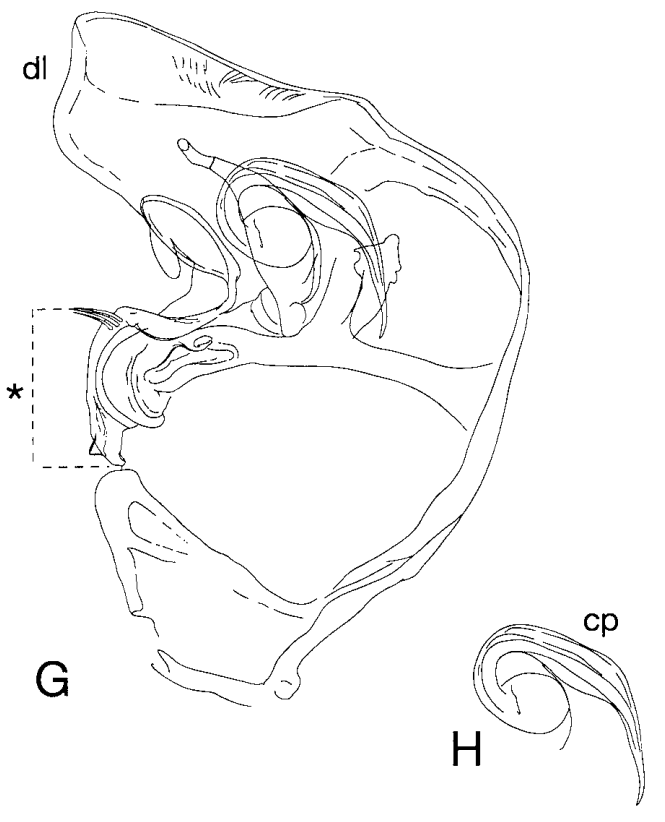

Fig. 4. Holotypes of Limnocythere kamiyai sp. nov., LBM 1430003503 (A, B), L. levigatus sp. nov., LBM 1430003509 (C, D), L. fude sp. nov., LBM 1430003507 (E, F), and L. cyphoma sp. nov., LBM 1430003517 (G, H). A, C, E, G, Hp; B, D, F, H, cp of Hp. 
elongate than male. Female with maximum height at anterior quarter, dorsal margin sloping down steeply to tightly curved posterior margin. Male dorsal margin with slight angle. Both sexes with sulcus. Female with well developed ala, this missing in male. L7 reduced, much smaller than L5 and L6. Male Hp very large, with finger-like projection on dl. Inner margin with large, hook-shaped structure and large brush of setae.

Description. Female carapace length $344-357 \mu \mathrm{m}$, height $214-221 \mu \mathrm{m}, \mathrm{H} / \mathrm{L}=$ $0.61-0.64$. Male carapace length $337-350 \mu \mathrm{m}$, height $169-178 \mu \mathrm{m}, \mathrm{H} / \mathrm{L}=0.50-0.51$. In lateral view maximum height at anterior third, marked by distinct dorsal hump (Fig. 2G). Straight hinge sloping down towards posterior margin at approximately $12^{\circ}$ angle. Posterior margin tightly curved, anterior margin rounded. Sulcus at mid-length, and with four tubercles, one on either side of sulcus near dorsal margin, two below dorso-anterior tubercle, and with large postero-ventral ala swept backwards with rounded end. In dorsal view posterior margin rounded, anterior margin beak-shaped (Fig. 2I). Surface of carapace covered with fine pits, these coarser in female than in male. Male carapace with maximum height at midlength, marked by subdued angular dorsal hump (Fig. 2H). Postero-dorsal margin with two denticles on right valve. Anterior margin evenly rounded. Ventral margin slightly concave. Sulcus at mid-length and with three tubercles: one on either side of sulcus near dorsal margin, and one at center point of carapace. Postero-ventral ala absent. Both male and female right valves with two tiny denticles on dorsal-posterior margin.

Appendages very similar to those of Limnocythere stationis, with exception of male Hp. Hp large and elongate. Inner edge with large, paintbrush-shaped group of fine setae pointing distally (marked with triangle on Fig. 4E) and large, robust, hook-like process. D1 large and sub-rectangular, with distinctive pointed process on distal-outer corner. $\mathrm{Cp}$ with stout wide base, tapering to long, flexible distal end (Fig. 4F).

Remarks. The male carapace of this species is similar to that of Limnocythere stationis, including the presence of two denticles on the posterior-dorsal margin of the right valve. The hinge, however, is slightly bent producing a weak dorsal hump, and the postero-ventral ala is absent. The hemipenes are very different in shape to those of the other species of Limnocythere from Lake Biwa, in particular the shape of the dl, the presence of the hook-like process, and the large, paintbrushshaped group of fine setae on the inner edge, indicating that it is a separate species. The females are slightly less elongate than those of $L$. stationis and the dorsal margin slopes towards the posterior margin at a steeper angle. The postero-ventral alae of the female are also much larger than those of $L$. stationis.

This species was found at a depth of $9.7 \mathrm{~m}$ in a substrate of poorly sorted, angular sand and gravel. Locality (Fig. 1): 16.

Etymology. Named after the Japanese calligraphy brush, "fude" (noun in apposition), due to the shape of the group of fine setae on the inner edge of the male Hp.

Limnocythere levigatus $\mathrm{sp}$. nov.

(Figs 4C, D, 5A-C)

Material examined. Holotype: male (LBM 1430003509), dissected, east side of 
northern basin of Lake Biwa, $35^{\circ} 13^{\prime} 54.1^{\prime \prime} \mathrm{N}, 135^{\circ} 57^{\prime} 49.6^{\prime \prime} \mathrm{E}$, pebbles, coarse angular sand, and some algae in $2 \mathrm{~m}$ depth of water, 16 June 2006. Allotype: female (LBM 1430003512), dissected, same data as holotype. Paratypes: dissected male (LBM 1430003513), whole male (LBM 1430003511), and whole female (LBM 1430003510), same data as holotype.

Diagnosis. Carapace with sulcus and three weakly-developed tubercles, one on either side of sulcus near hinge, the third located antero-ventrally, and with weakly developed postero-ventral ala. In dorsal view anterior end beak-like. Surface of valves covered with very small and shallow pits. Right valve with two denticles just posterior of hinge. L7 reduced, much smaller than L5 and L6. Hemipenes large and hook-shaped, with well-developed, tongue-shaped dl lobe.

Description. Carapace, female length $396-422 \mu \mathrm{m}$, height $227-234 \mu \mathrm{m}(\mathrm{H} / \mathrm{L}=$ $0.55-0.58)$, male length $318-351 \mu \mathrm{m}$, height $156-179 \mu \mathrm{m}(\mathrm{H} / \mathrm{L}=0.49-0.52)$. Female with slightly curved dorsal margin, with two denticles on postero-dorsal margin of right valve (Fig. 5A). Maximum height at anterior quarter of length, with gently curving dorsal margin sloping posteriorly from maximum height. Sulcus at mid-length with one weakly developed tubercle on either side of it near dorsal margin and one smaller tubercle below anterior one of these, and weakly developed ala near postero-ventral margin. Surface of carapace with very small pits towards posterior and anterior margins. In dorsal view anterior end beak-like, posterior end rounded (Fig. 5B). Male carapace considerably smaller and more elongate than that of female and lacking postero-ventral ala (Fig. 5C). Hinge straight, right valve with two small denticles on postero-dorsal margin.

Appendages similar to those of $L$. stationis, with exception of male Hp. Hp large, elongate, and broadly hook-shaped, wide distally (Fig. 4C). Outer margin well-rounded, dl tongue-like and rounded. Inner margin strongly indented, with strongly sclerotized margin supporting small number of setae towards proximal end (marked with asterisks in Fig. 4C). Cp with rounded, stout base, tapering to long, flexible distal end (Fig. 4D).

Remarks. This species is similar to Limnocythere stationis, but differs in the following: the carapace is much smoother with just fine pits towards the anterior and posterior margins; in dorsal view the tubercles are weakly expressed, especially the postero-ventral ala. The male hemipene is significantly different in shape, with the distal part much more developed than that of L. stationis.

This species was found three times at depths of 2 to 10 meters. Localities (Fig. 1): 5, 8, 29 .

Etymology. From the Latin adjective levigatus, meaning smooth or polished and referring to the smooth appearance of the carapace.

\section{Limnocythere cyphoma sp. nov.}

(Figs 4G, H, 5D-F)

Material examined. Holotype: male (LBM 1430003517), dissected, east side of the north basin of Lake Biwa, $35^{\circ} 09^{\prime} 52.0^{\prime \prime} \mathrm{N}, 136^{\circ} 03^{\prime} 44.2^{\prime \prime} \mathrm{E}$, beach at base of rocky shore, cobbles and boulders, with coarse angular sand, depth $0.2 \mathrm{~m}, 24$ August 2006. Allotype: female (LBM 1430003518), dissected, same data as holotype. Paratypes: dissected male (LBM 1430003519), whole male (LBM 1430003515), and 2 whole fe- 

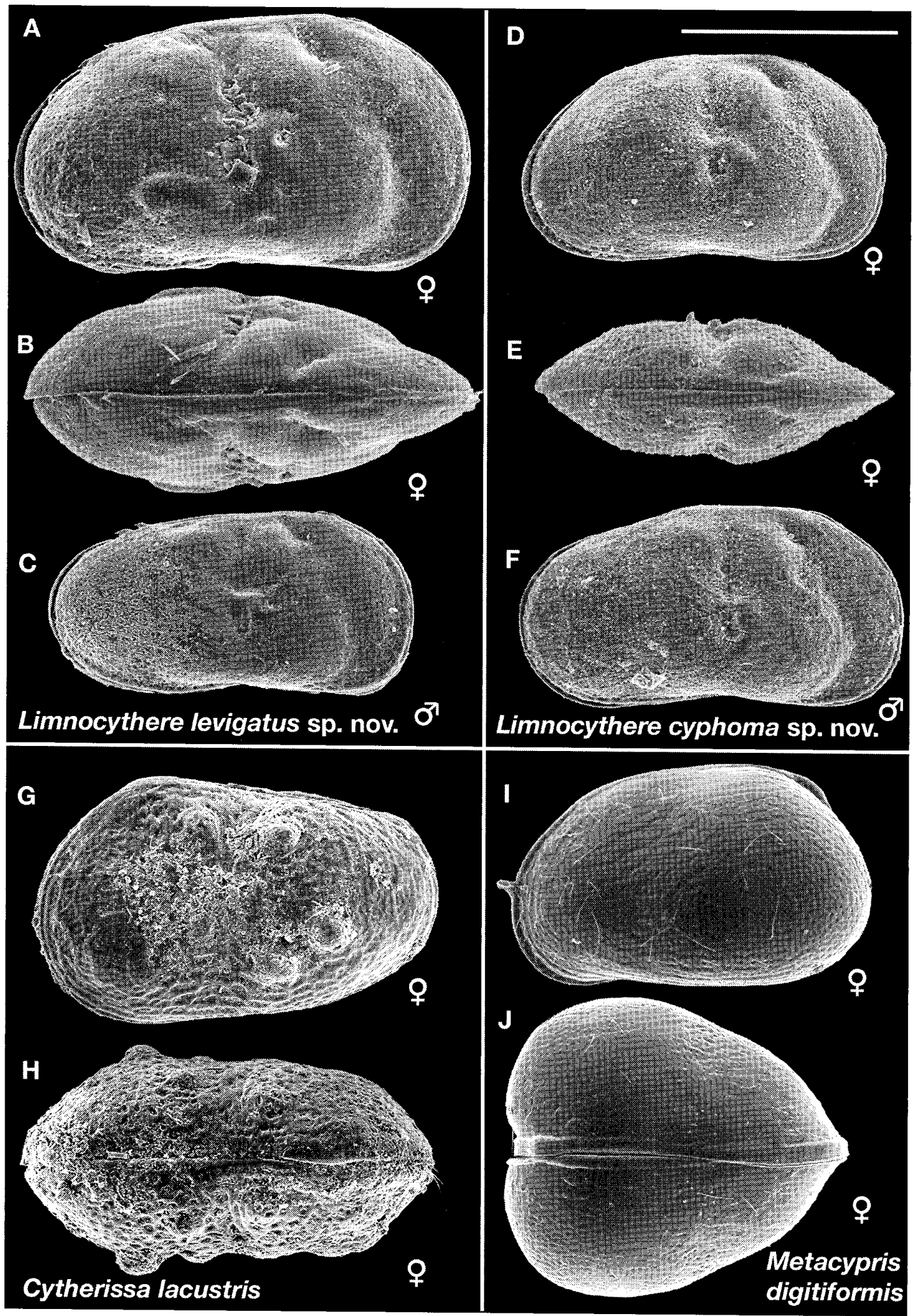
males (LBM 1430003514, LBM 1430003516), same data as holotype; 1 whole female (LBM 1430003520), west side of the north basin of Lake Biwa, $35^{\circ} 14^{\prime} 22.2^{\prime \prime} \mathrm{N}$, $135^{\circ} 58^{\prime} 13.7^{\prime \prime} \mathrm{E}$, very poorly sorted mud, sand, angular gravel, and organic detritus, depth 25 m, 10 June 2005; 1 male (LBM 1430003521), dissected, west side of the north basin of Lake Biwa, $35^{\circ} 13^{\prime} 54.3^{\prime \prime} \mathrm{N}, 135^{\circ} 57^{\prime} 48.4^{\prime \prime} \mathrm{E}$, gravel and sand, depth $9 \mathrm{~m}, 16$ June 2006.

Diagnosis. Very small carapace, less than $500 \mu \mathrm{m}$ in length, with sulcus and small indentation near anterior end of hinge. Male with bent dorsal margin. In dorsal view anterior beak-shaped and posterior pointed. Valve surface covered with very fine pits and weak reticulation. L7 reduced and significantly smaller than both L5 and L6. Male hemipenis large and L-shaped.

Description. Carapace length $331-337 \mu \mathrm{m}$, height $181-195 \mu \mathrm{m}$ in females $(\mathrm{H} / \mathrm{L}=$ $0.55-0.58)$, length $344-351 \mu \mathrm{m}$, height $181-188 \mu \mathrm{m}(\mathrm{H} / \mathrm{L}=0.53-0.54)$ in males. Male (Fig. 5F) elongate with anterior margin more inflated than posterior margin, ventral margin slightly concave, dorsal margin bent producing dorsal hump just posterior of mid-length. Carapace with sulcus at mid-length and small indentation near anterior end of hinge. Anterior end of carapace beak-like in dorsal view. Surface of valves covered with fine pits and weak reticulation. Female carapace (Fig. 5D, E) slightly smaller and less elongate than that of male, with straight hinge, sloping down to relatively tightly curved posterior margin.

Appendages very similar to those of L. stationis, with exception of Hp. Hp (Fig. $4 \mathrm{G})$ large and wide and approximately L-shaped. Dl rounded-rectangle with small, finger-like lobe projecting backwards on inner edge. Inner margin with well-sclerotized and slightly rounded edge supporting small number of short setae towards proximal end. Cp relatively long, robust and stout (Fig. $4 \mathrm{H}$ ).

Remarks. This species is similar to Limnocythere stationis but differs in the following: the female carapace is smaller and not so elongate; the postero-ventral tubercle is absent and the other tubercles are very weakly expressed; the surface of the valves is covered in very fine pores and weak reticulation; in dorsal view the posterior end of the carapace is more pointed; the male carapace is missing the two denticles on the right valve; the male carapace has a distinctive dorsal hump at mid-length; the male hemipenis is considerably different in form, being large and L-shaped.

Nineteen males and 16 females of this species were recovered from a boulder strewn coarse-sandy beach on the eastern side of the north basin (locality 44). One additional male (LBM 1430003521, length $422 \mu \mathrm{m}$, height $234 \mu \mathrm{m}$ ) was recovered at

Fig. 5. Limnocythere levigatus sp. nov. (A-C), L. cyphoma sp. nov. (D-F), Cytherissa lacustris (Sars, 1863) (G, H), and Metacypris digitiformis Smith and Hiruta, 2004 (I, J). A, Right view of female carapace; $\mathrm{B}$, dorsal view of female carapace, anterior to right; $\mathrm{C}$, right view of male carapace; $\mathrm{D}$, right view of female carapace; $\mathrm{E}$, dorsal view of female carapace, anterior to right; F, right view of male carapace; $\mathrm{G}$, female left valve, external view; $\mathrm{H}$, dorsal view of female carapace, anterior to right; $\mathrm{I}$, female left valve, external view; J, dorsal view of female carapace, anterior to right. A, B, LBM 1430003510, paratype; C, LBM 1430003511, paratype; D, LBM 1430003516, paratype; E, LBM 1430003514, paratype; F, LBM 1430003515, paratype; G, LBM 1430003525; H, LBM 1430003526; I, LBM 1430003522; J, LBM 1430003523. Scale bar $=195 \mu \mathrm{m}$ for A-F, $287 \mu \mathrm{m}$ for $\mathrm{G}$ and $\mathrm{H}$, and $481 \mu \mathrm{m}$ for I and $\mathrm{J}$. 
locality 29, and one additional female (LBM 1430003520, length $447 \mu \mathrm{m}$, height $244 \mu \mathrm{m}$ ) from locality 22 , both on the western side of the north basin. Compared to specimens recovered on the eastern side, these additional male and female are similar in morphology (including the male hemipenes), but the carapace is approximately $30 \%$ larger.

Etymology. After the Greek kyphoma (noun in apposition) meaning hump, referring to the humped dorsal margin of the carapace and strongly hunched outer margin of the Hp.

\section{Subfamily Timiriaseviinae Mandelstam \\ Genus Metacypris Brady and Robertson \\ Metacypris digitiformis Smith and Hiruta, 2004}

(Fig. 5I, J)

Metacypris digitiformis Smith and Hiruta, 2004: 38, figs 2, 3, 4A, B, 5.

Material examined. 1 female (LBM 1430003522, Fig. 5I), dissected, north part of north basin of Lake Biwa, $35^{\circ} 25^{\prime} 15.4^{\prime \prime} \mathrm{N}, 136^{\circ} 08^{\prime} 55.4^{\prime \prime} \mathrm{E}$, depth $0.8 \mathrm{~m}, 13$ August 2001; 1 whole female (LBM 1430003523, Fig.5J), same data; 1 male (LBM 1430003524), dissected, same data.

Remarks. This species has only previously been reported from marshlands in Hokkaido, northern Japan (Smith and Hiruta 2004). In Lake Biwa, specimens were collected from a gravelly substrate along a short stretch of the northern-most shore. Only ten adult female specimens and one badly preserved adult male were recovered, although juveniles were very abundant. Localities (Fig. 1): 6, 7.

\section{Family Cytherideidae Sars Genus Cytherissa Sars \\ Cytherissa lacustris (Sars, 1863)}

(Fig. 5G, H)

Cythere lacustris Sars, 1863: 222.

Cytherissa lacustris: Sars 1925: 153, pl. 70.

Material examined. 2 females (LBM 1430003525, Fig. 5G; LBM 1430003526, Fig. $5 \mathrm{H}$ ), whole, north basin of Lake Biwa, $35^{\circ} 11^{\prime} 50.9^{\prime \prime} \mathrm{N}, 135^{\circ} 59^{\prime} 13.6^{\prime \prime} \mathrm{E}$, mud, depth $70 \mathrm{~m}$, 10 June 2005; 1 female (LBM 1430003527), dissected, north basin of Lake Biwa, $35^{\circ} 14^{\prime} 22.2^{\prime \prime} \mathrm{N}, 135^{\circ} 58^{\prime} 13.7^{\prime \prime} \mathrm{E}$, very poorly sorted mud, sand, angular gravel, and organic detritus, depth $25 \mathrm{~m}$, 10 June 2005.

Remarks. This species was found at depths ranging from 25 to $87 \mathrm{~m}$, on a variety of substrates. It was most abundant on sediments rich in organic detritus. This species has a Holarctic distribution and is commonly found in the deeper, cooler parts of lakes (Meisch 2000). Localities (Fig. 1): 10-14, 17-19, 21-27, 29, 31-40, 42, 43. 


\section{Superfamily Darwinuloidea Brady and Norman \\ Family Darwinulidae Brady and Norman \\ Genus Darwinula Brady and Robertson \\ Darwinula stevensoni (Brady and Robertson, 1870)}

Polycheles stevensoni Brady and Robertson, 1870: 25, pls 7 (1-7), 10 (4-14).

Darwinula stevensoni: Brady and Robertson 1885: 346.

Darwinula improvisa: Turner 1895: 336, pl. 81 (1-3) (partim).

Darwinula protracta Roma, 1953: 39, pl. 2. [Synonymized by Rossetti and Martens 1996: 76]

Darwinula variabilis Tagliasacchi-Masala, 1968: 624, pls 3, 4. [Synonymized by Rossetti and Martens 1996: 76]

Darwinula sphenoides Rome in Rome and De Decker, 1977: 253, pl. 5. [Synonymized by Rossetti and Martens 1998: 59]

Material examined. 1 female (LBM 1430003250), dissected, south basin of Lake Biwa, $35^{\circ} 04^{\prime} 21.0^{\prime \prime} \mathrm{N}, 135^{\circ} 56^{\prime} 08.3^{\prime \prime} \mathrm{E}$, willow tree root mat, depth $0.1 \mathrm{~m}, 17$ April $2005 ; 1$ female (LBM 1430003251), dissected, south basin of Lake Biwa, $35^{\circ} 04^{\prime} 21.0^{\prime \prime} \mathrm{N}$, $135^{\circ} 56^{\prime} 08.3^{\prime \prime} \mathrm{E}$, willow tree (Salix sp.) root mat, depth $0.1 \mathrm{~m}, 7$ June 2005.

Remarks. Darwinula stevensoni is a cosmopolitan species, which in Lake Biwa was mostly found down to a depth of $5.6 \mathrm{~m}$, although one specimen was recovered from a depth of $26.6 \mathrm{~m}$. This species has been previously reported from Lake Biwa by Okubo (2001) and Smith and Kamiya (2008). Localities (Fig. 1): 1-5, 9, 15, 20 , 46-63.

\section{Genus Vestalenula Rossetti and Martens \\ Vestalenula danielopoli-group \\ Vestalenula cylindrica (Straub, 1952)}

(Figs 6A-H, 7, 8)

Darwinula cylindrica Straub, 1952: 497, figs 19-20.

Vestalenula cylindrica: Janz et al. 2001: 185, pl. 3 (22-26).

Vestalenula sp.: Smith and Kamiya 2008: 275-302, figs 15-17.

Material examined. 2 females (LBM 1430003528, LBM 1430003529), whole, south basin of Lake Biwa, $35^{\circ} 04^{\prime} 19.9^{\prime \prime} \mathrm{N}, 135^{\circ} 56^{\prime} 16.4^{\prime \prime} \mathrm{E}$, sand and organic detritus, depth $0.05 \mathrm{~m}, 28$ February 2005; 1 female (LBM 1430003530), dissected, south basin of Lake Biwa, $35^{\circ} 04^{\prime} 21.0^{\prime \prime} \mathrm{N}, 135^{\circ} 56^{\prime} 08.3^{\prime \prime} \mathrm{E}$, root mat of willow tree, depth $0.1 \mathrm{~m}, 22$ April 2005; 1 female (LBM 1430003531), dissected, south basin of Lake Biwa, $35^{\circ} 04^{\prime} 21.0^{\prime \prime} \mathrm{N}$, $135^{\circ} 56^{\prime} 08.3^{\prime \prime} \mathrm{E}$, root mat of willow tree, depth $0.1 \mathrm{~m}$, 5 July $2005 ; 1$ female (LBM 1430003532 ), dissected, south basin of Lake Biwa, $35^{\circ} 04^{\prime} 21.0^{\prime \prime} \mathrm{N}, 135^{\circ} 56^{\prime} 08.3^{\prime \prime} \mathrm{E}$, root mat of willow tree, depth $0.1 \mathrm{~m}, 5$ July 2005 .

Description. Carapace length $461-481 \mu \mathrm{m}$, height $208-221 \mu \mathrm{m}, \mathrm{H} / \mathrm{L}=0.45-0.46$. Lateral view elongate with straight hinge, anterior dorsal margin sloping to tightly curved anterior margin (Fig. 6A). Posterior margin evenly curved. Right valve (Fig. 6D) with elongate keel on ventro-posterior margin (Fig. 6C). Left valve internally with elongate tooth at ventro-anterior margin. Maximum width in dor- 

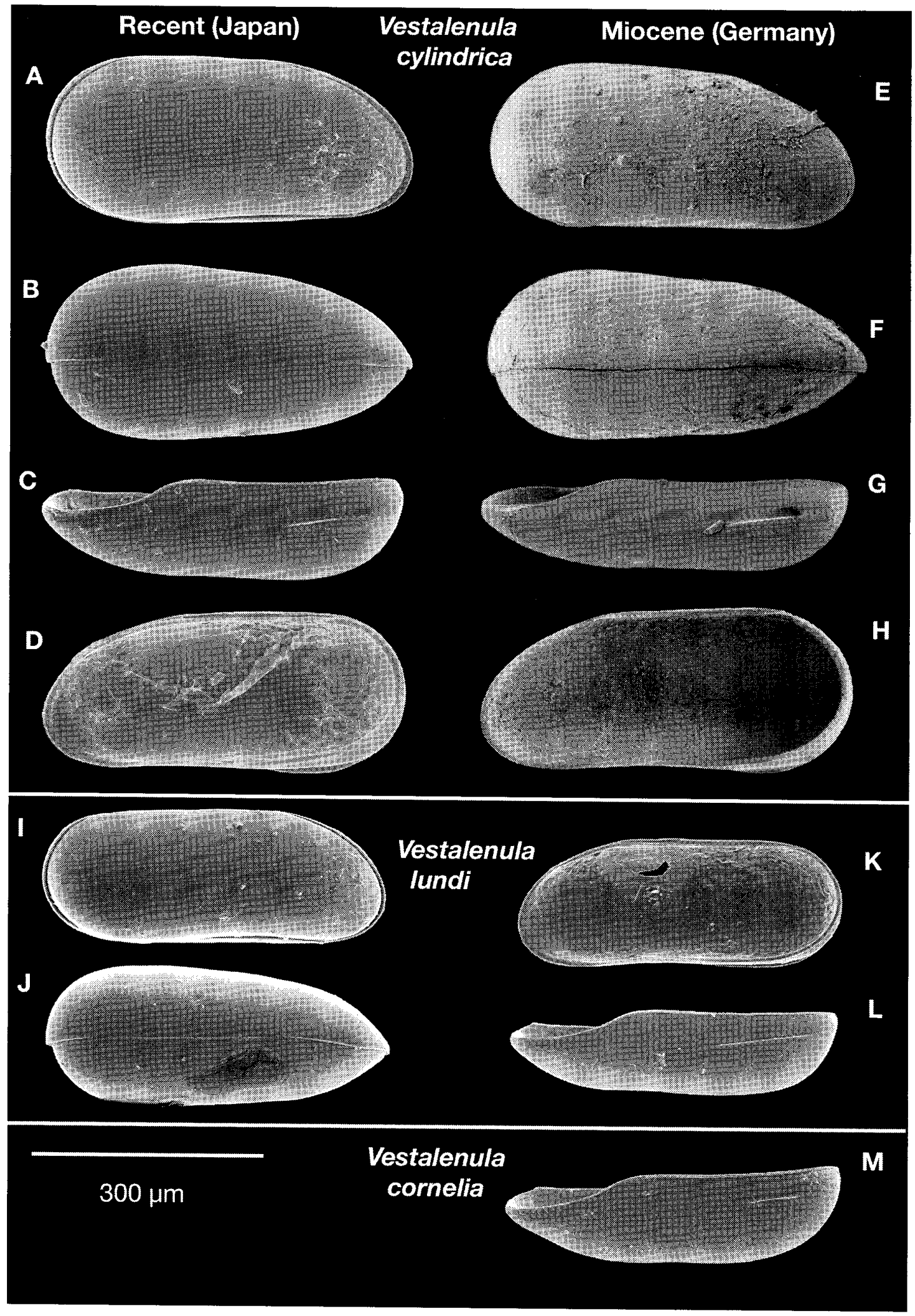
sal view at posterior third (Fig. 6B). Adductor muscle scars ranging from eight to ten in number, in typical darwinulid pattern (Fig. 7F).

Eye present. An1 (Fig. 7A) six-segmented, all segments short and robust. First segment with one dorsal seta. Second segment with one long and one short seta on apico-ventral corner. Third segment with robust but short apico-dorsal seta (s1). Fourth segment with short apico-dorsal seta (s2). Fifth segment with four apical setae, dorsal-most one longest. Final segment with two apical setae and short aesthetasc. An2 (Fig. 7B) with small hook h on first segment. Second segment with four small aesthetascs (Ac). Fourth segment with short $\mathrm{zl}$ claw, approximately $50 \%$ as long as G2 and G3 claws. Claw G3 very short, z2 tiny. Final segment with very small GM claw, less than half as long as $\mathrm{Gm}$.

Md (Fig. 7C) with long $z$ seta and medium-long $\mathrm{w}$ and $\mathrm{x}$ setae on second segment of palp. Final segment of palp with short c seta and five claws. Mx (Fig. 7D) palp two-segmented with two straight and one hooked setae on outer corner of first segment. Final segment small and quadrate, apically with two long and one short setae. Branchial plate with 24 normal and four reflexed rays.

L5 (Fig. 7E) with well-developed endite and three-segmented walking leg. Branchial plate (=exopodite) with 11 rays. L6 (Fig. 8A) five-segmented with short d1 seta and two d2 setae on first segment. Second segment with two e setae and long pd seta, latter extending past third segment. Third segment with robust $f$ seta. Fourth segment with small g seta. Final segment with robust h1 seta and h2 claw, and short, slender h3 seta. L7 (Fig. 8B) five-segmented with two d2 setae on first segment. Second segment with medium length e seta. Third segment with long $f$ seta, latter extending past fifth segment. Fourth segment with well developed $g$ seta. Final segment supporting very elongate claw h2 (approximately twice as long as L6 claw) and very long h1 seta, latter approximately $40 \%$ as long as claw. UR (Fig. 8C) with small, elongate base supporting slender claw. Lengths of base and claw fairly variable between specimens. Post-abdomen elongate.

Remarks. This species was first recorded from Lake Biwa by Smith and Kamiya (2008) as Vestalenula sp. Comparison with Miocene specimens of Vestalenula cylindrica from Germany (Fig. $6 \mathrm{E}-\mathrm{H}$ ) and other specimens in the published literature has determined that the Lake Biwa specimens are conspecific. Vestalenula cylindrica is known from Miocene deposits in Germany, Austria, Turkey, Slovakia, and Iran, Pliocene deposits of Turkey, and Pleistocene deposits of Portugal (Straub 1952; Lutz 1965; Freels 1980; Janz 1997; Witt 1998, 2000; Janz et al. 2001; Gross 2004; Pipík et al. 2004; Cabral et al. 2005; Minati et al. 2008). Herein is the first

Fig. 6. Vestalenula cylindrica (Straub, 1952), Recent, Lake Biwa (A-D) and Miocene, Germany, reproduced from Janz (1997) (E-H), V. lundi (Neale and Victor, 1978) (I-L), and V. cornelia Smith et al., 2006 (M). A, Right view of carapace (LBM 1430003529); B, dorsal view of carapace, anterior to right (LBM 1430003529); C, ventral view of right valve, anterior to left (LBM 1430003528); D, internal view of right valve (LBM 1430003528); E, external view of right valve (SMNS 62890/3); F, dorsal view of carapace, anterior to right (SMNS 62890/5); G, ventral view of right valve, anterior to left (SMNS 62890/4); H, internal view of right valve (SMNS 62890/2); I, right view of carapace (LBM 1430003533); J, dorsal view of carapace, anterior to right (LBM 1430003534); $\mathrm{K}$, internal view of right valve (LBM 1430003535); L, ventral view of right valve, anterior to left (LBM 1430003536); M, ventral view of right valve, anterior to left (LBM 1430000883). 


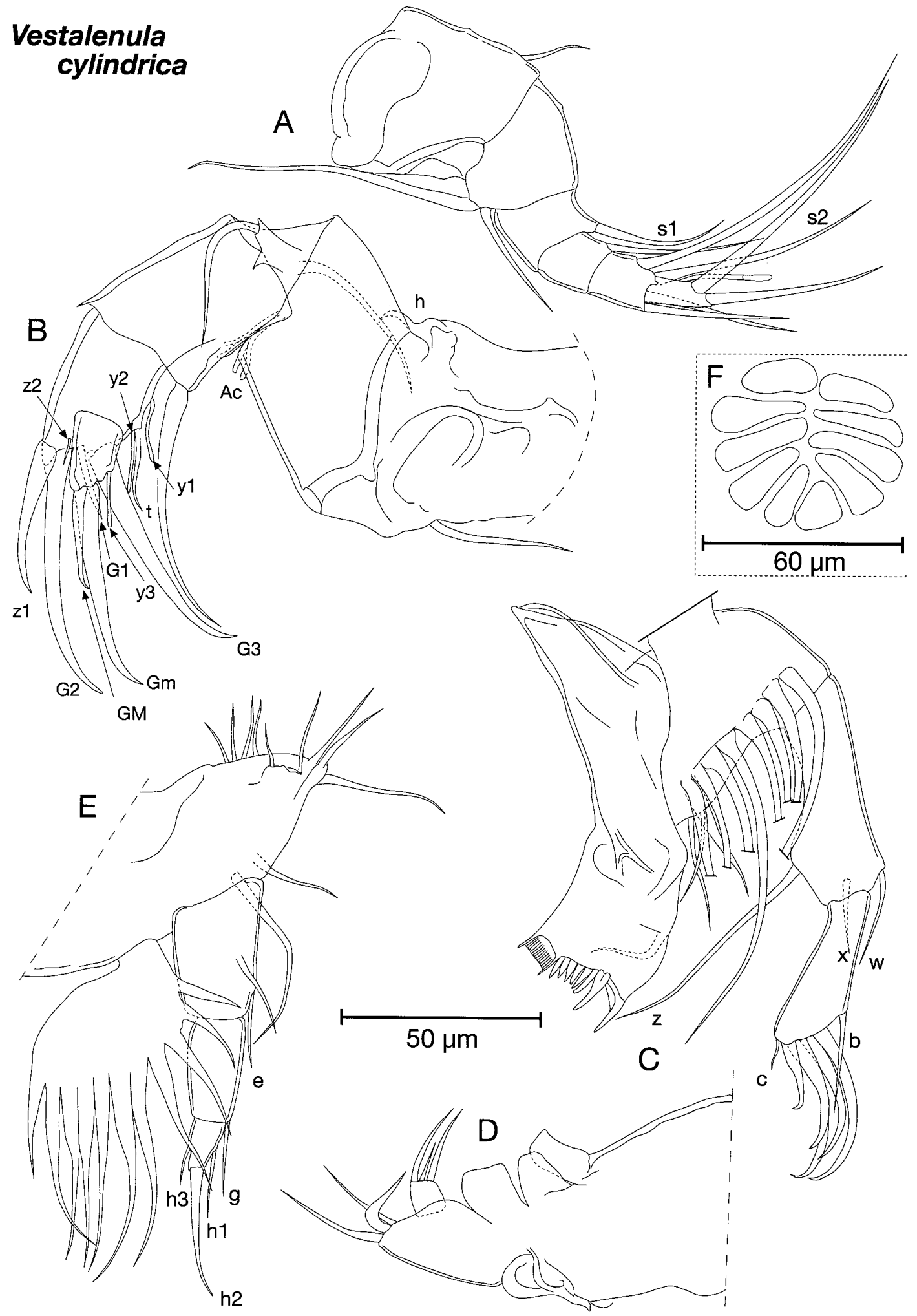

Fig. 7. Vestalenula cylindrica (Straub, 1952), LBM 1430003528 (A-C) and LBM 1430003530 (D, E). A, An1; B, An2; C, Md; D, Mx (setae on endites not drawn); E, L5; F, adductor muscle scars of left valve, internal view. 


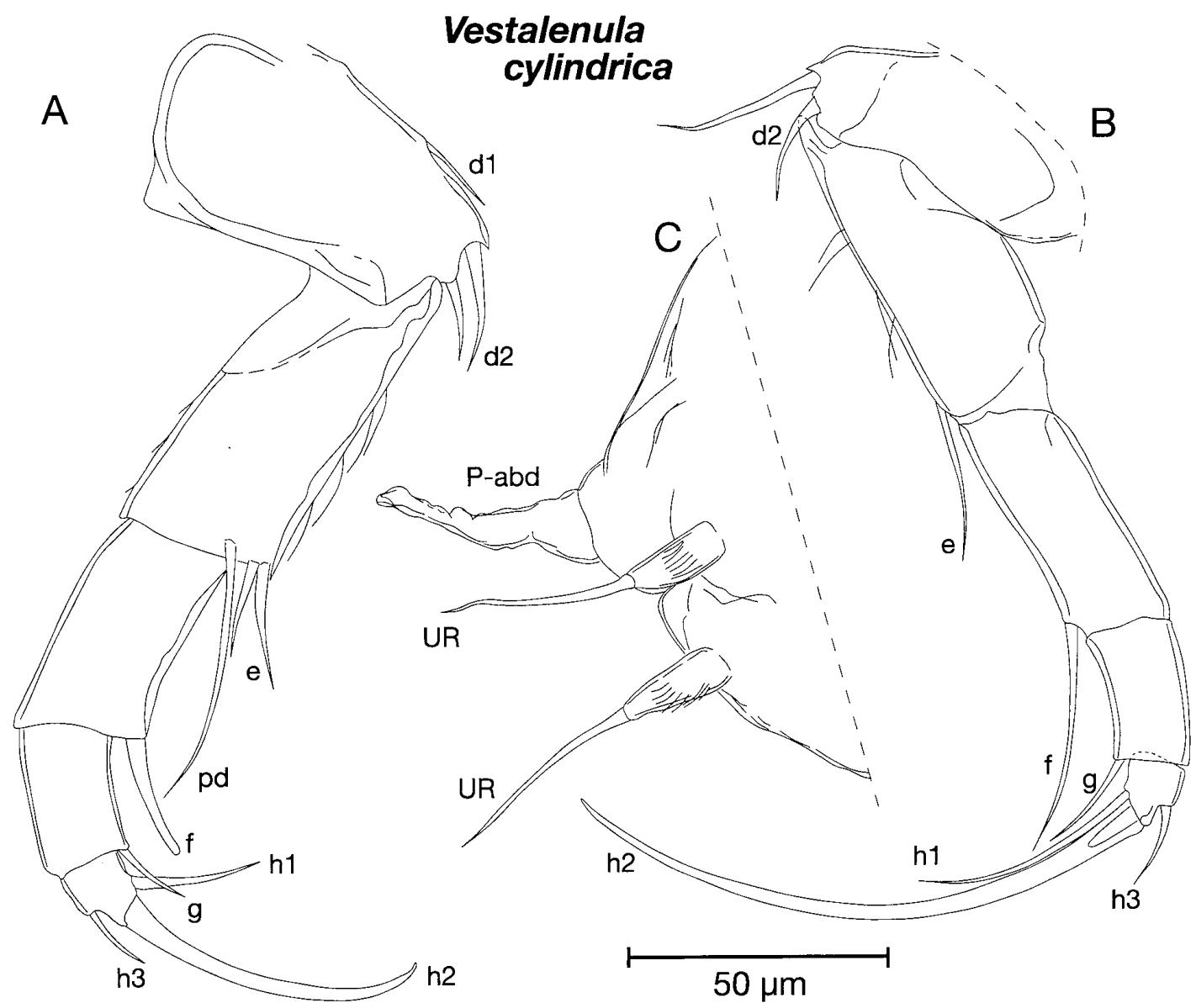

Fig. 8. Vestalenula cylindrica (Straub, 1952). A, L6 (LBM 1430003528); B, L7 (LBM 1430003528); C, UR (LBM 1430003531).

report of a living population and hence the first description of the appendages of this species. It differs from Vestalenula cornelia, the only other Vestalenula species previously known in Japan (Smith et al. 2006), in that its keel is longer (Fig. 6M), claw Gm is only half as long as GM (75\% in $V$. cornelia), claw G2 is proportionally shorter, and the carapace is slightly more elongate $(\mathrm{H} / \mathrm{L}=0.43-0.45$ compared with 0.47-0.49 for $V$. cornelia). Vestalenula carveli Artheau, 2007 is also very similar to $V$. cylindrica in carapace shape, but it is slightly more elongate than that of $V$. cylindrica, and $V$. carveli lacks an eye (Artheau 2007) (an eye is present in $V$. cylindrica).

This species was mainly recovered from shallow depths along the shore. Abundance was generally low, with the exception of the Karasuma Peninsula (site 55), where abundant specimens were recovered from the spongy, peaty root mats of willow trees lining the edge of the lake. Localities (Fig. 1): 29, 44, 46, 53, 55, 56.

Vestalenula lundi (Neale and Victor, 1978)

(Fig. 6I-L)

Darwinula lundi Neale and Victor, 1978: 1084, figs 7-12.

Vestalenula lundi: Rossetti and Martens 1998: 71, figs 9A-D, 25N-P. 
Material examined. 2 whole females (LBM 1430003533 Fig. 6I; LBM 1430003534, Fig. 6J), shore of north basin of Lake Biwa, $35^{\circ} 13^{\prime} 57.5^{\prime \prime} \mathrm{N}, 136^{\circ} 10^{\prime} 06.4^{\prime \prime} \mathrm{E}$, interstitial in poorly sorted sand pebbles and a little mud, depth $0.25 \mathrm{~m}, 24$ August 2006; 2 females (LBM 1430003535, Fig. 6K; LBM 1430003536, Fig. 6L), dissected, same data.

Remarks. In their taxonomic revision of the Recent and Holocene representatives of the family Darwinulidae, Rossetti and Martens (1998) stated in the diagnosis of Vestalenula lundi that it lacks a keel on the right valve. However, they went on to state that they were unable to definitively assess the presence or absence of a keel due to the decalcification of the type material. It is our opinion that this feature should therefore be excluded from the species diagnosis until its presence/absence can be confirmed in new material from the type locality. The specimens from Lake Biwa are otherwise identical with the redescription of this species by Rossetti and Martens (1998). As all other species of the genus Vestalenula have keels (so presumably the type specimens of $V$. lundi originally had keels before they became decalcified), we tentatively assign our specimens to $V$. lundi. Rossetti and Martens (1998) placed $V$. lundi in the $V$. boteai group, which is characterized by a short keel, although as no keel was observable in the type specimens the reasons for this placement are unclear. The keel on the right valve and the internal tooth in the left valve of the Japanese specimens are both elongate and demonstrate that this species belongs to the danielopoli group of Vestalenula. Vestalenula lundi was described based on specimens collected from a sandy riverbank with coarse gravel in Sri Lanka (Neale and Victor 1978). The specimens from Lake Biwa were abundantly recovered from interstitial samples from coarse sandy beaches. This is the first record of this species in Japan. Localities (Fig. 1): 28, 44.

Vestalenula boteai-group

Vestalenula molopoensis (Martens and Rossetti, 1997)

(Fig. 9A-D)

Darwinula molopoensis Martens and Rossetti, 1997: 59-60, figs 1, 3H-N. Vestalenula molopoensis: Rossetti and Martens 1998: 76, figs 11A-D, 27N-Q.

Material examined. 1 whole female (LBM 1430003537, Fig. 9A, B), $35^{\circ} 13^{\prime} 54.1^{\prime \prime} \mathrm{N}$, $135^{\circ} 57^{\prime} 49.6^{\prime \prime} \mathrm{E}$, shore of north basin of Lake Biwa, coarse, pebbly beach, depth $0.01 \mathrm{~m}, 9$ October 2007; 1 female (LBM 1430003538, Fig. 9C, D), dissected, same data.

Remarks. Only a few specimens of this species were collected together with many specimens of $V$. lundi, from a coarse sandy beach. Previously this species has been reported from South Africa and Thailand (Martens and Rossetti 1997; Savatenalinton et al. 2008). This is the first record of this species from Japan. Locality (Fig. 1): 44. 


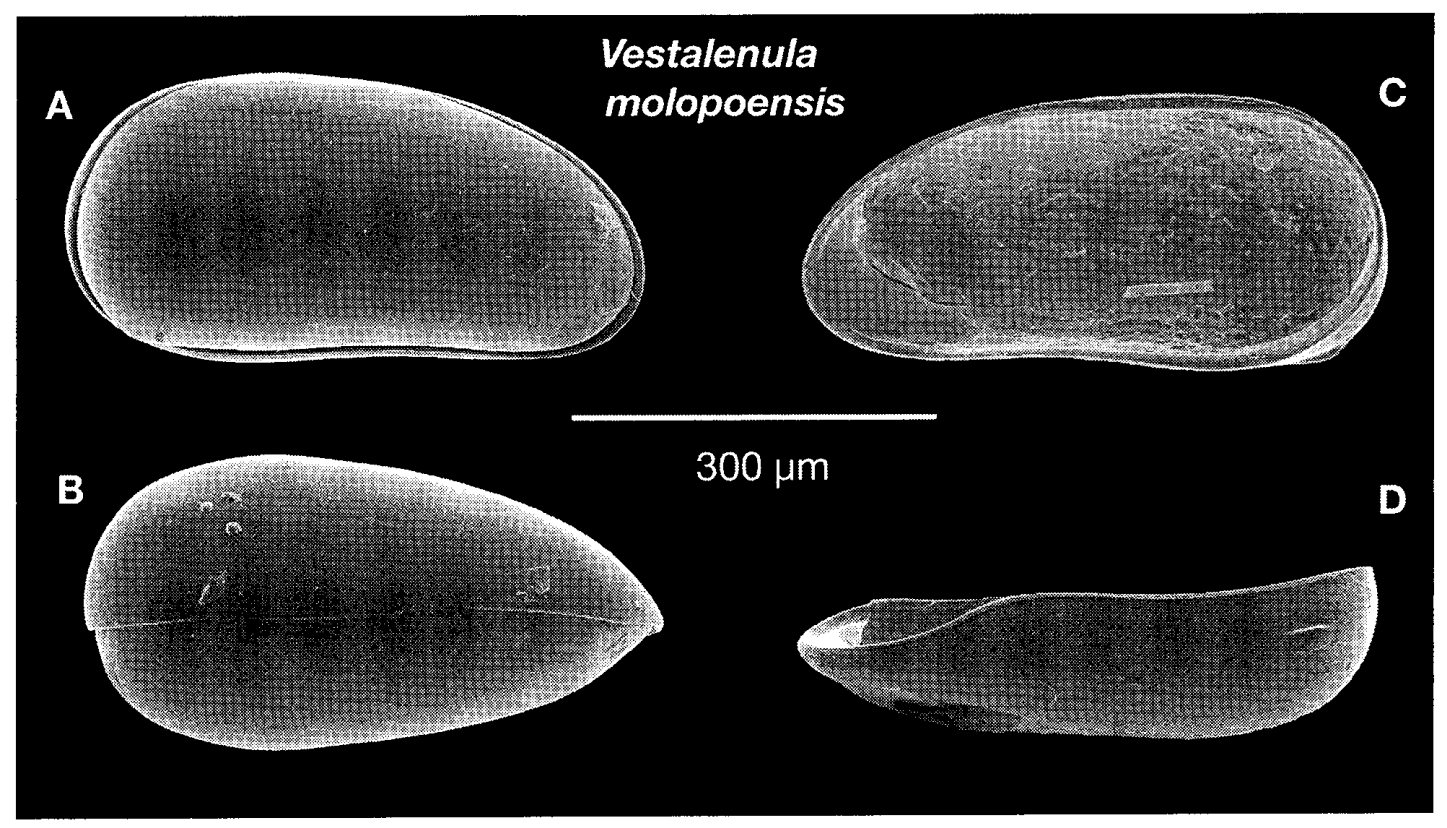

Fig. 9. Vestalenula molopoensis (Martens and Rossetti, 1997), LBM 1430003537 (A, B) and LBM 1430003538 (C, D). A, Right view of carapace; B, dorsal view of carapace, anterior to right; C, internal view of right valve; $\mathrm{D}$, ventral view of right valve, anterior to left.

\section{Discussion}

\section{The genus Limnocythere in Lake Biwa}

Five species of Limnocythere were recognized in the lake, including $L$. stationis, which is widely dispersed throughout Eurasia, parts of Africa, Uzbekistan, the Far-East of Russia, China, and Korea (Martens 1984; Meisch 2000; Schornikov and Trebukhova 2001; Schornikov 2004; Yu et al. 2005). The other four Limnocythere species so far only known from Lake Biwa may be an example of a small species flock that has evolved from the much more widely distributed $L$. stationis. These four species all have a subtly different carapace shape compared with $L$. stationis, but they show a strong resemblance to it; with the exception of the hemipenes, the appendages of all five species are indistinguishable between species, including the reduced seventh limb. The hemipenes, however, are very different in each of the five species, clearly indicating that, although the carapace and appendage morphologies are very similar, they are five distinct species. In light of the similar carapaces and similar habitats in which the five species were found, the significant differences in morphology among their relatively very large hemipenes suggest a strong influence of sexual selection in this lineage. All five species were only found a very small number of times, and hence it is possible that further sampling of Lake Biwa may reveal more species in this lineage.

\section{The genus Vestalenula in Lake Biwa}

The discovery of two more Vestalenula species in Lake Biwa brings the total for Japan to four (and the number of darwinulids in Japan to five). Three species, 
Table 1. Comparison of the four species of Vestalenula so far reported from Japan.

\begin{tabular}{lccc}
\hline \multicolumn{1}{c}{ Species } & $\begin{array}{c}\text { Length of } \\
\text { carapace }(\mu \mathrm{m})\end{array}$ & $\begin{array}{c}\text { Height/length of } \\
\text { left valve }\end{array}$ & $\begin{array}{c}\text { Length of keel (\% of } \\
\text { right valve length) }\end{array}$ \\
\hline$V$. lundi & $429-442$ & $0.39-0.42$ & 31 \\
$V$. cylindrica & $461-481$ & $0.45-0.46$ & 26 \\
$V$. cornelia & $427-449^{*}$ & $0.47-0.49$ & 20 \\
$V$. molopoensis & $448-474$ & $0.50-0.51$ & 7 \\
\hline
\end{tabular}

Data are for Japanese specimens only.

* From Smith et al. (2006).

namely $V$. cylindrica, $V$. lundi, and $V$. cornelia, have long keels (Fig. 6, Table 1 ) and hence belong to the $V$. danielopoli-group of Rossetti and Martens (1998). Vestalenula molopoensis has a much shorter keel and belongs to the $V$. danielopoli-group of Rossetti and Martens (1998), representing the first report of this group in N. E. Asia. Previously the genus Vestalenula has been considered to contain many endemic species (e.g., Rossetti and Martens 1999; Martens and Rossetti 2002; Artheau 2007), but the presence of $V$. cylindrica, $V$. lundi, and $V$. molopoensis in Japan, many thousands of kilometers away from previous records, suggests that this apparent high rate of endemism may partly be an artifact of a lack of sufficient sampling in many regions of the world.

\section{Acknowledgements}

The authors thank Machiko Nishino (Lake Biwa Environmental Research Institute), Mark J. Grygier, Hiroki Haga, Kenichi Kohashi, Yasushi Kusuoka, Kazuhiro Masunaga, Katsuki Nakai, Kenji Nakazono, Satoshi Ohkawa (all of the Lake Biwa Museum), Toru Ishii (University of Kanazawa), and the captain and crew of the Hakken-go (Lake Biwa Environmental Research Institute) for help in collecting samples. Ronald Böttcher (Editor of Stuttgarter Beiträge zur Naturkunde Serie B (Geologie und Paläontologie), Stuttgart Museum) is thanked for kindly granting us permission to reproduce figures of Vestalenula cylindrica from Janz (1997). We also thank Renate Matzke-Karasz (Ludwig-Maximilians University) and David J. Horne (Queen College, University of London) for reviewing the manuscript and their helpful comments. This study is part of the Lake Biwa Museum Comprehensive Research Project on the exploration and systematics of the aquatic biota of Shiga Prefecture (S06-02).

\section{References}

Artheau, M. 2007. Geographical review of the ostracod genus Vestalenula (Darwinulidae) and a new subterranean species from southern France. Invertebrate Systematics 21: 471-486.

Brady G. S. and Robertson, D. 1870. The Ostracoda and Foraminifera of tidal rivers. Part 1. Annals and Magazine of Natural History, Series 4, 6: 1-33.

Brady G. S. and Robertson, D. 1885. [No title]. In: Jones, T. R. On the Ostracoda of the Purbeck 
Formation with notes on the Wealden species. Quarterly Journal of the Geological Society of London 41: 311-353.

Cabral, M. C., Colin, J.-P., Carbonel, P. 2005. Espèces pléistocènes de la famille Darwinulidae Brady et Norman, 1889 (Ostracodes), en Algarve, sud Portugal. Revue de Micropaléontologie 48: 51-62.

De Deckker, P. 1981. Ostracoda from Australian inland waters-notes on taxonomy and ecology. Proceedings of the Royal Society of Victoria 93: 43-85.

Freels, D. 1980. Limnische Ostrakoden aus Jungtertiär und Quartär der Türkei. Geologisches Jahrbuch 39: 3-169.

Gross, M. 2004. Zur Ostracodenfauna (Crustacea), Paläoökologie und Stratigrafie der Tongrube Mataschen (Unter-Pannonium, Steirisches Becken, Österreich). Joannea Geologie und Paläontologie 5: 61-62.

Horne, D. J. 2003. Key events in the ecological radiation of the Ostracoda. In: Park, L. E. and Smith, A. J. (Eds) Bridging the gap, trends in the ostracode biological and geological sciences. Paleontological Society Papers 9: 181-201.

Janz, H. 1997. Die Ostrakoden der Kleini-Schichten des miozänen Kratersees von Steinheim am Albuch (Süddeutschland). Stuttgarter Beiträge zur Naturkunde, Serie B (Geologie und Paläontologie) 251: 1-101.

Janz, H., Jellinek, T. and Hamedani, A. 2001. Holozäne Süßwasser-Ostracoden aus dem Iran. Senckenbergiana Lethaea 81: 183-205.

Lutz, A.-K. 1965. Jungtertiäre Süsswasser-Ostracoden aus Süddeutschland. Geologisches Jahrbuch 82: 271-330.

Martens, K. 1984. On the freshwater ostracods (Crustacea, Ostracoda) of the Sudan, with special reference to the Red Sea Hills, including a description of a new species. Hydrobiologia 110: 137-161.

Martens, K. 1994. Ostracod speciation in ancient lakes: a review. In: Martens, K., Goddeeris, B. and Coulter, G. (Eds) Speciation in ancient lakes. Advances in Limnology 44: 203-222.

Martens, K. and Rossetti, G. 1997. On two new species of Darwinula Brady and Robertson, 1885 (Crustacea, Ostracoda) from South African dolomitic springs. Bulletin de l'Institut Royal des Sciences Naturelles de Belgique, Biologie 67: 57-66.

Martens, K. and Rossetti, G. 2002. On the Darwinulidae (Crustacea: Ostracoda) from Oceania. Invertebrate Systematics 16: 195-208.

Meisch, C. 2000. Freshwater Ostracoda of Western and Central Europe. Süßwasserfauna von Mitteleuropa 8/3. Spektrum Akademischer Verlag, Heidelberg, Berlin, 522 pp.

Meisch, C. 2007. On the origin of the putative furca of the Ostracoda (Crustacea). Hydrobiologia 585: $181-200$.

Meyers, P. A., Takemura, K. and Horie, S. 1993. Reinterpretation of the late Quaternary sediment chronology of Lake Biwa, Japan, from correlation with marine glacial-interglacial cycles. Quaternary Research 39: 154-162.

Minati, K., Cabral, M. C., Pipík, R., Danielopol, D. L., Linhart, J. and Neubauer, W. 2008. Morphological variability among European populations of Vestalenula cylindrica (Straub) (Crustacea, Ostracoda). Palaeogeography, Palaeoclimatology, Palaeoecology 264: 296-305.

Mori, S. and Miura, T. 1990. List of plant and animal species living in Lake Biwa (corrected third edition). Memoirs of the Faculty of Science, Kyoto University, Series B 14: 14-22.

Nakajima, T. and Nakai, K. 1994. Lake Biwa. In: Martens, K., Goddeeris, B. and Coulter, G. (Eds) Speciation in ancient lakes. Advances in Limnology 44: 43-54.

Neale, J. W. and Victor, R. 1978. The Lund University Expedition freshwater Ostracoda from Sri Lanka (Ceylon). Canadian Journal of Zoology 56: 1081-1087. 
Nishino, M. and Watanabe, N. C. 2000. Evolution and endemism in Lake Biwa, with special reference to its gastropod mollusc fauna. Pp. 151-180. In: Rossiter, A. and Kawanabe, $\mathrm{H}$. (Eds) Ancient Lakes: Biodiversity, Ecology and Evolution. Advances in Ecological Research, 31. Academic Press, San Diego.

Okubo, I. 2001. Freshwater ostracod Darwinula stevensoni from Lake Biwa. Bulletin of the Biogeographical Society of Japan 56: 39-43. [In Japanese]

Okubo, I. 2004. Nihon Tansui-san Kaimijinko-rui ni Tsuite [Freshwater Ostracoda of Japan]. Self-published, Okayama, Japan, 72 pp. [In Japanese]

Pipík, R., Fordinál, K., Slamkova, M., Starek, D. and Chalupova, B. 2004. Annotated checklist of the Pannonian microflora, evertebrate and vertebrate community from Studienka, Vienna Basin. Scripta Facultatis Scientiarum Naturalium Universitatis Masarykianae Brunensis 31/32: 47-54.

Rome, D. R. 1953. Ostracodes cavernicoles de la Grotte Tsebahu, Mont Hoyo (Irumu, Congo Belge). Revue de Zoologie et de Botanique Africaines 47: 34-42.

Rome, D. R, and De Deckker, P. 1977. Ostracodes du Lac Kivu. Mémoires de l'Institut Géologique de l'Université de Louvain 29: 241-287.

Rossetti, G. and Martens, K. 1996. Redescription and morphological variability of Darwinula stevensoni (Brady and Robertson, 1870) (Crustacea, Ostracoda). Bulletin de l'Institut Royal des Sciences Naturelles de Belgique, Biologie 66: 73-92.

Rossetti, G. and Martens, K. 1998. Taxonomic revision of the Recent and Holocene representatives of the family Darwinulidae (Crustacea, Ostracoda), with a description of three new genera. Bulletin de l'Institut Royal des Sciences Naturelles de Belgique, Biologie 68: 55-110.

Rossetti, G. and Martens, K. 1999. Contribution to taxonomy and distribution of the genus Vestalenula Rossetti and Martens, 1998 (Crustacea, Ostracoda, Darwinulidae), with the description of two new species. Bulletin de l'Institut Royal des Sciences Naturelles de Belgique, Biologie 69: 57-66.

Rossiter, A. 2000. Lake Biwa as a topical ancient lake. Pp. 571-598. In: Rossiter, A. and Kawanabe, H. (Eds) Ancient Lakes: Biodiversity, Ecology and Evolution. Advances in Ecological Research, 31. Academic Press, San Diego.

Sars, G. O. 1863. Beretning om en i Sommeren 1862 foretagen zoologisk Reise i Christianias og Trondhjems Stifter. Nyt Magazin for Naturvidenskaberne 12: 193-252.

Sars, G. O. 1925. Ostracoda. Pp. 73-208. In: Sars, G. O. (Ed.) An Account of the Crustacea of Norway with Short Descriptions and Figures of All the Species. Vol. IX. Bergen Museum, Bergen.

Savatenalinton, S., Borgonie, G. and Martens, K. 2008. On Thaicythere srisumonae n. gen., n. sp. (Ostracoda) from Thailand, with notes on the phylogeny of the subfamily Timiriaseviinae Mandelstam, 1960. Crustaceana 81: 411-432.

Schornikov, E. I. 2004. Crustacea: Ostracoda. Pp. 458-465. In: Tyurin, A. N. and Drozdov, A. L. (Eds) Far-Eastern Marine Biospherical Reserve. Biota. Vol. 2. Dalnauka, Vladivostok. [In Russian]

Schornikov, E. I. and Trebukhova, Y. A. 2001. Ostracods of brackish and fresh waters of southwestern coast of Peter the Great Bay. Pp. 56-85. In: Kasyanov, V. L., Vaschenko, M. A. and Pitruk, D. L. (Eds) The State of Environment and Biota of the Southwestern Part of Peter the Great Bay and the Tumen River Mouth. Dalnauka, Vladivostok. [In Russian]

Smith, R. J. and Hiruta, S. 2004. A new species of Metacypris (Limnocytherinae, Cytheroidea, Ostracoda, Crustacea) from Hokkaido, Japan. Species Diversity 9: 37-46.

Smith, R. J. and Janz, H. 2008. Recent species of the family Candonidae (Ostracoda, Crus- 
tacea) from the ancient Lake Biwa, Central Japan. Journal of Natural History 42: 2865-2922.

Smith, R. J. and Kamiya, T. 2001. The first record of an entocytherid ostracod (Crustacea: Cytheroidea) from Japan. Benthos Research 56: 57-61.

Smith, R. J. and Kamiya, T. 2008. The ontogeny of two species of Darwinuloidea (Ostracoda, Crustacea). Zoologischer Anzeiger 247: 275-302.

Smith, R. J., Kamiya, T. and Horne, D. J. 2006. Living males of the 'ancient asexual', Darwinulidae (Ostracoda, Crustacea). Proceedings of the Royal Society B 273: 1569-1578.

Straub, E. W. 1952. Mikropaläontologische Untersuchungen im Tertiär zwischen Ehingen und Ulm an der Donau. Geologisches Jahrbuch 66: 433-524.

Tagliasacchi-Masala, M. L. 1968. Gli Ostracodi delle sorgenti thermali di Sardara (Sardegna meridionale). Rendiconti del Seminario della Facoltà di Scienze della Università di Cagliari 37: 613-630.

Turner, C. H. 1895. Fresh-water Ostracoda of the United States. Geological and Natural History Survey of Minnesota, Zoological Series 2: 277-337.

Vávra, W. 1891. Monographie der Ostracoden Böhmens. Archiv der Naturwissenschaftlichen Landesdurchforschung von Böhmen 8: 1-116.

Witt, W. 1998. Die miozäne Fossil-Lagerstätte Sandelzhausen 14. Ostracoden. Mitteilungen der Bayerischen Staatssammlung für Paläontologie und Historische Geologie 38: 135-165.

Witt, W. 2000. Süßwasserostracoden der miozänen Vorlandmolasse Süddeutschlands. Mitteilungen der Bayerischen Staatssammlung für Paläontologie und Historische Geologie 40: $109-151$.

Yu, N., Zhao, Q., Schornikov, E. L. and Chen, L. 2005. Recent ostracods from the Taihu Lake. Acta Micropalaeontologica Sinica 22: 143-151. [In Chinese with English abstract]

Zhao, Y. 1987. On Limnocythere xinanensis Zhao sp. nov. Stereo-Atlas of Ostracod Shells 14: 127-130. 